\title{
Global Food Governance
}

\author{
Nora McKeon ${ }^{1}$
}

Published online: 6 September 2021

(c) Society for International Development 2021

\begin{abstract}
This article helps lay a basis for the kind of deep analysis of the stakes of global food governance that is required today, under the impact of the COVID-19 crisis and with the threat of corporate capture of decision-making spaces. The article reviews the history of global food governance, identifies the critical questions that need to be asked, and suggests some directions that may contribute to strengthening the agency of rights-holders, weakening that of corporations, and democratizing multilateral governance.
\end{abstract}

Keywords Human rights · Corporations · COVID-19 · Evidence $\cdot$ United Nations

Food is at the heart of whatever humanity gets up to, collectively or singly, in all cultures. It was the first thought of the iconic British figure Robinson Crusoe when he found himself alone on a deserted island, while the mythical peasant woman Nyéléni's capacity to keep her entire community well-provisioned merited her choice as the symbol of the first international food sovereignty conference in Mali in 2007. Food has imprinted the astoundingly rich variety of cultural evolutions and spiritual reflections to which societies have given birth and has orchestrated humanity's interaction with nature as well. Domestication of plants and animals went hand-in-hand with the development of sedentary communities, not only in the Fertile Crescent that dominates western imaginaries but also in the Yellow and Yangtze River basins of China with millet and rice, and in Central and the Andean Americas with maize, potatoes and other crops (Barker 2006). The identification of these evolutions with unconditioned progress, as in modernization theory, has been disproven but not unseated by accumulating evidence of their arguable impacts in terms of the introduction of socio-economic inequalities, the deterioration of diets as compared with those of hunter-gathers, or the salinization of irrigated soils that contributed to the downfall of the Sumerian civilization. Food-and the tools, salt and spices needed to hunt or grow, preserve and flavour it—was also the

Nora McKeon

nora.mckeon@fastwebnet.it

1 International University College of Turin and Roma Tre University, Terra Nuova, Rome, Italy earliest motivation of the barter and trade that have knit societies together in increasingly lengthy and complex circuits.

All of this has required governance, not always benign by any means as demonstrated by the existence of slavery and the exploitation of women associated with food provisioning in many societies across the ages. Nonetheless, a good deal of pre-capitalist food governance respected what historian E.P. Thompson suggestively termed the 'moral economy', in which the privileges of the elite were accompanied by responsibility for ensuring the food security of their subjects (Thompson 1963). The process whereby this preindustrial conception was progressively replaced by the market economy, fuelled by capitalism and tempered by social pressures to introduce rationalized notions of civil society and social protection, was described in an influential work by economic historian Karl Polanyi (1957), who posited a continuing open-ended dialectic between social selfprotection and the excesses of capital accumulation. This is the dialectic in which an increasingly large proportion of the world's population has found itself entangled over the past decades. Food regime theorists have described it in terms of successive periods in which dominant actors have sought to organize agro-food trade in order to optimize capitalist accumulation, the first led by imperial Great Britain in the period 1870s-1930s, the second by the USA in the post-war period (1950s-1970s), and the third (1970s-present, butvacillating today under the onslaught of multiple crises)—by corporate actors (Friedmann and McMichael 1989).

The same periodization, read through the lens of the institutional history of global governance, restitutes similar 
lessons. Nineteenth century imperialism and the new forms of accumulation it introduced produced much of the foundation for the technical and managerial aspects of global governance as we see it today, aimed particularly at regulating and extending the world market and industrial capitalism and attenuating its social costs (Gill 2019). A classic account of this process distinguishes three generations of the multiple international organizations created after 1850 , articulated around the construction of successive world orders following periods of upheaval (Murphy 1994). Explicit attention to the specific issue of global food governance was born in the preWorld War II period when the League of Nations was invited to address the co-existence in the world of widespread malnutrition and global over-availability of food, occasioning acrimonious debate that was cut off by the advent of the war (Shaw 2007).

Three milestones of post-World War II global food governance-the creation of the UN Food and Agriculture Organization (FAO) in 1944, the World Food Conference in 1974, and the reform of the UN Committee on World Food Security (CFS) in 2009-were all prompted by massive food crises whose implications the international community could not ignore (McKeon 2015). The institutional provisions they introduced, however, did not and could not suffice to address the cumulative structural issues that underlay the crises: the colonial extraction of commodities to provide cheap food for workers and raw materials for industries at the expense of the colonized (Watts 1983; Davis 2000); the post-war dumping of US grain surpluses under the guise of food aid and the induced indebtedness of countries in the Global South geared to soaking up the excess liquidity of banking institutions in the Global North; the neo-liberal policies introduced from the 1970s with the effect of reducing the policy space of governments of 'developing' countries, opening their countries' markets and exposing their small-scale producers to unfair competition from subsidized food products from abroad. Each of these global food governance milestones, and their deficient attempts to resolve the underlying problems, have lessons to teach us for the present and the future.

In a book on food governance that I published a few years ago I tried to make sense of what I had observed in five decades in the food world with one foot in African villages and the other in UN conference rooms (McKeon 2015). Already at that time my verdict was that 'the history of post-World War II food governance is essentially one of selling out public responsibility to markets and corporations' to the detriment of the majority of the world's population and the planet we inhabit. 'It is one of progressive disempowerment of the primary food security actors: the smallscale producers and the family units in whom immediate concern for food provision is invested' (McKeon 2015: 3). The same period, however, had also witnessed the growth of an increasingly robust, diversified and articulated network of these producers and other social actors ill-served by the corporate-led globalized food system. These movements were resolutely engaged in defending and building ecologically and socially sustainable, territorially embedded food provisioning arrangements that tend to be termed 'alternative' although they are responsible for up to $70 \%$ of the food consumed in the world. The key word in describing the dialectic between these two dynamics, I concluded, was power in all of its declinations: power to frame the food agenda, power to weigh in when decisions are being made, poweror lack thereof - to uphold the rights of the vulnerable and the public interests that are fundamental to the well-being of today's and future generations.

The COVID-19 pandemic is serving to expose and exacerbate the dramatic food provisioning choice that confronts us today and the structural issues underlying it: corporateled global supply chains rooted in environmentally destructive industrial agriculture and churning out unhealthy processed food, on the one hand, or territorially-embedded food systems fed by agro-ecological family farming and attentive to the social relations and the cultural, ecological and health dimensions of food provisioning on the other. History teaches us that moments of crisis represent extraordinary opportunities both for consolidation of power and for transformation. Never before has it been so critical to get the architecture of global food governance right.

\section{Understanding Food Governance: Where are We at Now?}

The past few years have seen a multiplication of literature reviews of global food governance in an effort to introduce clarity into what increasingly appears to be a strategic but elusive topic. A study on Strengthening the food systems governance evidence base conducted by the Consultative Group on International Agricultural Research (CGIAR) conventionally opted for taking the three dimensions of production, distribution and consumption as the framework for the review but concluded by underlining the need to introduce critical research on food governance to avoid a purely functionalist approach (Aodan et al. 2016). A systematic literature review undertaken at Wageningen University did a better job of capturing the complexity of the topic and its exquisitely political dimensions (Candel 2014). Food security is a highly complicated and multi-dimensional issue that is impacted by a broad range of drivers and food system activities, stretches across various scales, and involves multiple sectors and policy domains. It is affected by a wide array of governance regimes that are constituted by distinct sets of actors, forums, discourses, interests, which affect one another through their norm-setting tasks, the creation of rules and diffusion of paradigms. In short, a 'wicked 
problem', a category that has been defined as policy problems that are 'not only complex, but also ill-defined, ambiguous, contested and highly resistant to solutions' (Candel 2014). In the more colloquial terms of an artisanal fisher friend, getting a handle on food governance is like grabbing a fistful of eels in a barrel: however hard you try something always wriggles away.

The outcome of the eel grabbing exercise is not casual, of course, since the hand can be wide open or tight-fisted. Commenting on the results of the milestones of global food governance above, John Shaw (2016) notes that 'they were most often more about what big powers didn't want than what they wanted to do'. The proposed World Food Board and the International Trade Organization, on the table but vetoed by the USA when the international food governance architecture was being designed in the post-World War II period, would have gone a long way towards regulating global food flows in the name of food for all (Friedmann 2015). The ill-fated, inadequately mandated World Food Council established by the 1974 World Food Conference was a poor compromise between the authoritative World Food Security Council proposed by some and the heel-dragging of those who did not want to set up any new UN machinery that might effectively address structural issues. The food crisis of 2007-2008 revealed, once again, a policy vacuum whereby-in the absence of an authoritative dedicated policy forum-decisions in this key area were being taken by default by restricted clubs of the rich countries, international bodies like the World Trade Organization (WTO) working to other mandates or, worse still, private economic and financial actors subject to no political oversight. If the outcome - the reform of the UN Committee on World Food Security-was a break with the past it can be attributed to a particular political context in which some key Latin American countries were able to ally with a few European defenders of the right to food, the Food and Agricultural Organization under the leadership of a strong-willed African director-general, and the combative food sovereignty movement which by then had built its advocacy power up to the global level.

We will return to the CFS in a moment, since it is the kingpin of a better food governance system, but for now let us trace the evolution of food governance following the critical questions: what is it that needs to be governed? By whom? How? For what purpose? These are the kind of questions that political scientist and former UN official Robert Cox termed 'critical' in that they help to identify contradictions and potential transformations towards a different kind of global governance, as opposed to 'problem-solving' and technocratic approaches that seek to extend the existing order (Gill 2019). They are precisely the kind of questions we need to ask today, on the 75th anniversary of the UN, when 'let's just get it done' solutions are being shoved down our metaphoric throats by corporate activists and complicit governments. Let us adopt these questions as a framework to briefly assess where we are.

The 'what' of food governance has evolved steadily if not consistently. From the purely productivist, supply-side orientation adopted by the 1974 World Food Conference ${ }^{1}$ the concept of 'food security', understood as the objective of food governance, subsequently moved on to encompass concerns about access, stability and utilization or nutritional quality. The definition used by the CFS since 2002 expands the idea of access and adds a nod towards culture: 'Food security exists when all people, at all times, have physical, social and economic access to sufficient safe and nutritious food that meets their dietary needs and food preferences for an active and healthy life'. ${ }^{2}$ This extension of scope, however, has not sheltered the concept of food security from criticism. The first to attack it were civil society actors, who noted during the World Food Summit in 1996 that it failed to address the important questions of where food should be produced, how, by whom, for whose benefit, and under whose control (McKeon 2015: 76). These questions, which Cox would have judged eminently critical, have continued to frame the food fight up to today.

The productivist birth of global food governance and the trade interests of powerful political and economic actors have determined a focus on value chains as what need to be governed, an orientation that continues to surface in moments of crisis despite its evident inadequacy, as we will see when we examine the impacts of the COVID-19 pandemic. Nonetheless, over the past few years there has been a progressive shift towards the far more comprehensive concept of 'food systems', described by the CFS High Level Panel of Experts in the following terms: 'A food system gathers all the elements (environment, people, inputs, processes, infrastructures, institutions, etc.) and activities that relate to the production, processing, distribution, preparation and

\footnotetext{
1 Where food security was defined as 'availability at all times of adequate world supplies of basic food-stuffs to sustain a steady expansion of food consumption and to offset fluctuations in production and prices'.

2 A report by the High-Level Panel of Experts (HLPE) of the Committee on World Food Security published in 2020 adds two important additional dimensions: agency, defined as 'individuals or groups having the capacity to act independently and make free choices about what they eat and how that food is produced, processed, and distributed'; and sustainability, defined as 'food system practices that contribute to the quality of the natural environment on a long-term basis, ensuring the food needs of the present generations are met without depleting natural resources faster than they can be regenerated, and that the interrelationships between ecological systems and food systems remain viable'. This significant extension of the concept of food security has still not been politically debated in the CFS and is opposed by the powerful commodity exporting countries. (HLPE 2020).
} 
consumption of food, and the outputs of these activities, including socio-economic outcomes' (HLPE 2014). There is agreement among a wide range of actors on the need to go beyond an agriculture-based approach to include considerations of nutrition, climate, health and others, but consensus ends there. The definition and regulation of food systems is the current battleground of food governance. It is being waged in policy negotiations in the inclusive CFS where small-scale producers, consumers and other social actors are pushing for a systemic understanding of the profound transformation required for the health and well-being of the planet and its populations, ${ }^{3}$ and in narrative positioning for the corporate-led UN Food Systems Summit (FSS) ${ }^{4}$ - to which we will return - which is profiling a high-tech future laced with omnipresent digitalization and medicalization of nutrition by substituting manufactured food supplements for naturally healthy produce.

Ideas concerning 'by whom' and 'how' food should be governed at global level have also evolved. ${ }^{5}$ Sovereign states engaged in political deliberation in splendid isolation in the UN and FAO from their foundation to the 1980s, when a series of factors stimulated the UN system to open up to other actors, principally civil society and the private sector (McKeon 2009). The CFS, reformed in an unprecedentedly inclusive process in 2009 , moved up to pole position in the line-up for inclusive global food governance within a multinational human rights framework by assigning priority voice to those actors most impacted by the policies under discussion while retaining final decision-making for governments and hence maintaining their accountability (McKeon 2011). The opposing vision, dubbed 'multi-stakeholderism', has been elaborated by the World Economic Forum (WEF) through a process of 'Global Redesign' which involves replacing what is judged to be a clumsy, ineffective multilateral system with a series of "coalitions of the willing

\footnotetext{
3 The Civil Society and Indigenous Peoples Mechanism rejected the outcome of the negotiations in the CFS for the adoption of Voluntary Guidelines on Food Systems and Nutrition that concluded in February 2021 as ' a lost opportunity to guide a much-needed radical transformation of food systems around the globe and effectively tackle the root causes of the growing hunger crisis' (https://www.csm4cfs.org/ civil-society-indigenous-peoples-new-cfs-voluntary-guidelines-foodsystems-nutrition-fail-pave-way-profound-transformation/).

${ }^{4}$ For civil society critiques of the UN Food Systems Summit see the letter addressed by over 300 organizations to the UN SecretaryGeneral last February, which has remained without response. https:// www.foodsovereignty.org/csos-letter-on-un-food-systems-summit/ and a subsequent letter addressed to the Chair of the Committee on World Food Security: http://www.csm4cfs.org/letter-csm-coordinati on-committee-cfs-chair/.

5 This discussion is limited to formal global governance. A good deal of the decision-making that impacts on food provisioning is de facto exercised by agro-food corporations managing supply chains without political oversight.
}

and able' charged with addressing burning global problems. Each of these is led by corporate actors who are presumed to have the necessary know-how, managerial capacity and resources to make things happen, if not the willingness to be subject to accountability for the outcomes of what does happen (Gleckman 2018). This is the vision that animates the UN FSS, although it has been ably fabulized by corporate spin docs to present itself as a 'People's Summit'.

'How' and 'for what purpose' go hand-in-hand with 'who'. When the food price crisis made the headlines in 2007-2008 with riots in capital cities around the world the international community's initial reaction took the 'business as usual' form of enhanced administrative efficiency through the creation of a consortium of the secretariats of UN agencies and programmes impacting on food security coupled with a call to establish a donor-managed fund to direct more aid and investment to agriculture, without reflecting on what model needed to be promoted. The proposal to reform the CFS was the only one which acknowledged the structural causes of the crisis and the need to seek policy solutions through political negotiation, with the public sphere taking responsibility for regulating private sector activities in the public interest. The objective, here, is realization of the human right to adequate food for all. The WEF and UN FSS approach, instead, places the accent on action through public-private partnerships in which blended public financing and policy adjustments create a 'favourable environment' for the corporate investments without which, it is assumed, no solutions to hunger can be found. The vision, here, is one of the effectiveness of technological innovations and marketled solutions which should somehow translate into growth that benefits all, belying the evidence of steadily increasing inequalities within and between countries. Food as a human right versus food as a marketed good is still at the heart of the fight for food governance, 75 years down the road.

The reformed CFS was born into a global governance universe that that stacked the cards on the side of the corporations. Global governance was fragmented and incoherent. Private actors loomed large. Matters such as competition policy, food safety, public health and poverty reduction, were not well coordinated on a world scale. Regulatory capacity had not kept pace with the global integration of markets for goods, services and money (Clapp and Cohen 2009), and with the galloping development of game-changing technology. A balance sheet I drew up in 2015 listed nine problematic aspects of global food governance that the CFS needed to address: (1) fragmentation, (2) lack of inclusiveness of those most affected, (3) insufficiently human rights based, (4) dominance of productivist and 'free' market paradigm as the route to food security, (5) top-down articulation among different levels (6) inadequate implementation, monitoring, and promotion of accountability, (7) power relations affecting-decision making, particularly corporate influence, 
(8) spread of informal, private sector or hybrid mechanisms lacking political oversight, and (9) lack of effective, enforceable regulation. In this assessment the CFS was judged to have had some success in dealing with the first four and to be making efforts to tackle the fifth and sixth. The last three, I noted then, are the most difficult to address since they get to the heart of the power relations that keep the corporate-led global food system in place (McKeon 2015: 191).

A subsequent article, three years later, noted that the political context has worsened since the time of the CFS reform. Corporate power in food chains has continued to grow and financialization is transforming food and land into objects of speculation. World-wide, there is a trend towards shrinking space for civil society and reduced ambition for defending human rights. The primacy and legitimacy of the public sector is threatened by corporate capture of policy spaces and a development narrative that assigns a lead role to external private sector investment, while multilateralism is under attack from virulently populist nationalism and corporation-promoted multi-stakeholderism (McKeon 2018).

At the same time, FAO's The State of Food and Nutrition Security in the World 2021 reported an increase in the number of hungry people for the fifth year running, with the impacts of COVID-19 likely to continue to add substantially to this figure over the next years (FAO 2021). The pandemic has both unveiled and aggravated the structural issues that have put us severely off track to achieve SDG 2 on hunger and nutrition by 2030. The world's food systems require radical transformation and the inclusive governance vision embedded in the CFS needs to be defended and extended. What would it take to get us there?

\section{What Would it Take to Achieve Better Food Governance?}

Knowledgeable diagnoses of what is blocking beneficial change in our food systems and their global governance have multiplied as evidence of the damage they have wrought to people and the planet has accumulated. Some of the more thoughtful have been produced by the Independent Panel of Experts on Sustainable Food Systems (IPES-Food), and the autonomous High-Level Panel of Experts (HLPE) of the CFS.

In a report arguing for a transition to agroecology IPESFood identified a series of lock-ins of industrial agriculture whose dismantling would require public policy action. Some of these are related to political structures governing food systems, some to how agricultural markets are organized. There are conceptual barriers around the way questions are framed: path dependency, export orientation, expectation of cheap food, compartmentalized and short-term thinking, productionist 'feed the world' narratives along with loaded indicators of success. Finally, concentration of power reinforces all of the others (IPES-Food 2016). A report the following year looking at how to overcome the negative impacts of increasing corporate concentration along the food chain recommended building a new anti-trust environment, introducing transnational oversight of agri-food consolidation, promoting new, people-centred knowledge and innovation paradigms and developing new economic paradigms to ensure equitable supply systems (IPES-Food 2017).

For its part, the already cited forward-looking report on 'Food Security and Nutrition: Building a Global Narrative Towards 2030' commissioned by the CFS and published by the HLPE in June 2020 calls for four critical policy shifts: policies that promote radical transformation of food systems in the direction of greater equity, sustainability and territorial embeddedness; policies that appreciate the interconnectedness of different systems and sectors; policies that address hunger and malnutrition in all its forms and encourage a diversity of fresh, local fruits and vegetables; and policies that develop context-specific solutions taking local conditions and knowledge into account. All of this must be upheld by effective governance centred on the right to food and other human rights, with the CFS playing a lead role given its legitimacy founded on inclusiveness, government accountability and a solid autonomous evidence base for policy deliberation (HLPE 2020).

The stumbling block these carefully reasoned analyses encounter is always the same: in the end it is a question of political will, and political will — in this age of largely unenlightened leaders and powerful economic actors-is difficult to muster without significant levels of politically effective popular mobilization. There is no doubt that the time is ripe for negotiation of a new social contract governing food provision, but the social actors in place during Polanyi's 1950s vision of a great transformation are weak or absent and the new ones are perhaps too fragmented and scattered.

I closed my 2015 book with the question 'Why is this time different?' My answer then had to do with the ecological, socio-economic and political limits of the accumulation modalities of the current form of capitalism and, in parallel, with the mounting force of alternative ways of food provisioning. The experience of the COVID-19 has confirmed the validity of these factors, as demonstrated in the testimony of communities and constituencies around the world collected by the CSM. ${ }^{6}$ The corporate offensive on global governance

\footnotetext{
6 'Voices from the ground: from Covid 19 to radical transformation of our food systems' https://www.csm4cfs.org/csm-global-synthesisreport-covid-19/, 'Gender, COVID-19 and Food Systems: impacts, community responses and feminist policy demands' https://www. csm4cfs.org/csm-women-report-covid-19/, and Youth Demands for a Radical Transformation of our Food Systems https://www.csm4cfs. org/csm-youth-policy-declaration-covid-19/.
} 
itself is mounting, however, with the UN FSS in the forefront. Democratic space is under attack at all levels. Nor are the multilateral forums of the UN exempt from democracy deficiencies, with less powerful countries disadvantaged and marginalized social actors practically excluded. Here are a few directions in which we could work towards better governance of a better food system by strengthening the agency of rights-holders, strategically limiting the power of corporate and financial actors, and subjecting the UN system to a hefty dose of democratization.

\section{Connecting the Dots in an Extended Human Rights Framework and Thinking Out of the (Western) Box}

The human rights framework, adopted only three years after the founding of the UN, is the best basis we have for sovereign states to be called to account by the 'we the peoples' who speak in the UN's Charter. The roster of rights has been extended over the years from the political rights on which Western states put the accent at the outset to economic and social rights and beyond, with the UN Declaration on the Rights of Indigenous Peoples (UNDRIP) in 2007 and the UN Declaration on the Rights of Peasants and Other People Working in Rural Areas (UNDROP) in 2018. The indivisible nature of rights-in areas ranging from food to health, women, workers-has never been as clear as it is now under the impact of COVID-19. We need to connect the dots and build collective agency among the fragmented pieces of the UN system deputized to defend them.

We need also to seriously consider the extension of rights to nature, as in the constitution of Ecuador and national and local regulations in a number of countries. For sure, in framing the issues of food provisioning and governance we need to think outside of the (western) box with more determination than we have shown thus far. We need to learn from other cosmologies rather than just making politically correct gestures in their direction. Indigenous Peoples have lessons to teach us which we can no longer afford to ignore about the importance of re-integrating humanity within nature and outlawing forms of profit-making that damage the web of life and the planet that sustains it. We need to move past the black and white state-market dichotomy and find space for other ways of configuring and governing territories seen through a lens of political ecology, such as thinking of Lake Superior not as a border between two sovereign states but as a common, living resource to be managed by those who live around it (Friedmann 2015; McKeon 2016). Another imperative is that of taking feminist analysis seriously, not just as one perspective among others but as a profound rereading of all aspects of the transformation of food systems and governance (CSM 2019).

\section{Waging the Battle of Narratives and 'Evidence'}

Closely related to the above is the push for victory in narrative battles that seemed to be just losing fights only a few years ago. Corporate discourse may seem a poor cousin to economic muscle but it does perform the important functions of legitimizing the global food system and stifling public awareness of the stakes involved. Broader acceptance of agroecology as the better way to go than industrial agriculture is a prime example of how narratives can evolve. We are well aware of the capacity of the proponents of the corporate global food system to co-opt language and concepts, and indeed agro-ecology is the object of such an exercise right now as retail chains develop their own brands in which some agronomic practices are excised from the broader understanding of the social, cultural, ecological and political implications of agro-ecology. ${ }^{7}$ Nonetheless, the side battling for alternative narratives has going for it the fact that their discourse corresponds to the complex nature of reality to a far greater degree than do the simplistic market and technology-based messages of the corporate cohorts. Narrowly defined agro-ecological products produced according to a corporate logic might possibly have some positive effects on the environment, but they can never contribute to employment creation, improving the nutritional status of neighbouring communities or strengthening the social and economic texture of family farms the way peasant agroecology does.

The COVID-19 pandemic is helping to unveil such realities. Small-scale producers and other social actors fought hard in the CFS for recognition that most of the food consumed in the world transits through territorial, or 'informal' markets rather than formal value chains and supermarkets, finally winning policy recommendations in this sense in 2016 (CFS 2016; CSM 2016). When COVID-19 hit, the ideologically and economically influenced knee-jerk reaction of governments was to close 'unsafe' territorial markets and to concentrate on keeping global supply chains moving and 'modern, safe' supermarkets open. Popular protest and reality checks quickly led many authorities-at local levels above all-to reopen the territorial markets on which the majority of the population depends for nutritious fresh

\footnotetext{
7 The recently concluded negotiations in the CFS on 'Agroecological and Other Innovative Approaches for Sustainable Food Systems that Enhance Food Security and Nutrition', conducted on the basis of an excellent report by the HLPE (2019), illustrate the urgency of protecting the inclusive multilateral space of the CFS from the rights-trampling action of powerful commodity exporting states and their corporate allies, as described in the declaration of the CSM to the CFS Plenary session during which the negotiation outcome was adopted (https://www.csm4cfs.org/csm-declaration-cfs-policy-recommenda tions-agroecological-innovative-approaches/).
} 
foods, and global governance spaces are now increasingly recognizing the fragilities of global supply chains as compared with territorial food systems. They are also starting to accept the need to adopt diversified food safety approaches based on a calculation of the actual risks incurred in any particular environment rather than universalized ideas of 'hazards' conceived with industrialized food and supermarket retailing in mind.

Corporate narratives get by with generalities and slogans such as the productivist 'How to feed 9 billion people by 2050?' Alternative narratives gain ground by clearly defining problems, making distinctions and recapturing meanings. The World Economic Forum and the UN FSS now wring their hands and generically lament that food and agriculture are responsible for all sorts of climatic, environmental and health problems, without taking the trouble to distinguish between differential impacts of industrial agriculture/global supply chains as compared with peasant agro-ecology/territorial food systems. The UN FSS thinks of assembling the components of food systems as though they were beads to be strung together one after another, and talks about handling trade-offs as though it were a poker game. The alternative narrative is cognizant of the complex ways in which different components of food systems interact and influence one another and exempts human rights from the trade-off game. Here too the inclusive CFS, where smallscale producers and other social constituencies can bring their own evidence, is a hot-bed of reality-rooted clarity as compared with other UN forums (HLPE 2019; CSM 2019). ${ }^{8}$

\section{Rebuilding Food Governance (and Democracy) from the Bottom Up and Out, with a Helping Regulatory Hand from Above}

If the CFS constitutes the advanced frontier of inclusive multilateral governance it is because its reform was not the outcome of a technocratic drawing board exercise or governmental dictat but of two decades of mobilization and networking by small-scale producers and other social constituencies, from local to global levels. For governance to function in a people and planet-friendly way people need to exercise their agency as citizens and communities rather than as individual consumers/economic actors in a market logic. This is an apprenticeship that most often works best at the local level to start with, where authorities are closest

\footnotetext{
${ }^{8}$ It is not by coincidence that one of the main offensives launched in the context of the FSS is the push to substitute a closed box 'pure' science-policy interface on food systems for the innovative CFS's High-Level Panel of Experts which recognizes the validity of a diversity of forms of knowledge-from western science to indigenous and peasant-and opens the framing document and initial draft of its report to broad consultation.
}

to reality and to community pressure. If reality is a valiant arm for fighting false narratives, connectedness is one for building political power against the isolation and the separation of producer and consumer induced by the market and the divisiveness of populist, nationalist we-they discourse. Rebuilding connectedness starts in the community but requires convergence to be politically effective: intersectional convergence at all levels, across issue areas and identities, that builds a common understanding of the threats posed by corporate capture of the economy and democracy and stimulates common action against them (McKeon and Berron 2020).

There is, of course, a dialectic relationship between the different levels in this regard. ${ }^{9}$ Among the helping hands that the global level can provide to people's movements mobilizing from below are a staunch defence of the need to site policies and action within a normative frame based on indivisible human rights and of the public sphere as the legitimate and accountable space responsible for setting the rules for private sector action and making sure they are respected. The policy guidance that the CFS provides is valuable and needs to be applied more vigorously (HLPE 2020). It is increasingly evident that mandatory global regulation is needed in such areas as assessment of new technology and monitoring and limiting corporate concentration (ETC 2018).

\section{Conclusions}

We are living in a complex world in which the multiple uncertainties that we face are not amenable to taming via indisputable scientific evidence or audacious technological innovation (Scoones et al. 2020). In the optic of working towards better governance of better food systems they can only be addressed by political decision-making of the kind that can lead to a new social contract within a human rights framework, based on what is deemed to be most beneficial for the planet and the people who inhabit it - the now vulnerable majority rather than the now privileged few-and endowed with a participatory monitoring capacity that enables adjustments as conditions evolve. Learning from the COVID-19 pandemic, the dimensions of solidarity and cooperation triumph.

Exercises in redesigning global governance in the UN tend to take the form of institutional adjustments when they are conducted by the initiated, as though adding a couple of states to the Security Council would make the difference. Let's take the challenge out of the hands of the insiders

\footnotetext{
9 Some prefer the term 'transcalar' to avoid binominal 'global-local' terminology and to emphasize the multi-directionality of relations and influences.
} 
and put it back in the real world. After over two decades of state-bashing on the part of people's movements seeking justice and equity, in the present atmosphere of corporate concentration and authoritarian populist nationalism a growing number of social actors are re-discovering the benefits of multilateral governance, providing it can be put to the defence of the public sphere, public interests and human rights. The inclusive CFS is a space in which this can and does happen and this is why it is the place to start in linking up the currently fragmented and often contradictory international forums that impact on food systems. Who would have foreseen, a decade ago, that a popular movement might rise up to defend the CFS against the Food System Summit's effort to engineer corporate capture of global food governance? If we play our cards right, we might actually move closer towards a People's UN.

\section{References}

Aodan, Delaney, T. Evans, Jordan McGreevy, T. Schlachter, Kaisa Korhonen-Kurki, Peter A. Tamás, Todd A. Crane, H. Eakin, Wiebke Förch, L. Jones, D.R. Nelson, Michael Obersteiner and M. Purdon. 2016. Strengthening the food systems governance evidence base: Supporting commensurability of research through a systematic review of methods. CGIAR Research Programme on Climate Change, Agriculture and Food Security, working paper 167.

Barker, Graeme. 2006. The agricultural revolution in prehistory, why did foragers become farmers? Oxford: Oxford University Press.

Candel, J.J.L. 2014. Food security governance: A systematic literature review. Food Security 6 (4): 585-601.

Civil Society and Indigenous Peoples Mechanism (CSM). 2016. Connecting smallholders to markets: an analytical guide. http://www. csm4cfs.org/connecting-smallholders-markets-analytical-guide/

Civil Society and Indigenous Peoples Mechanism (CSM). 2019. Without feminism there is no agroecology! http://www.csm4cfs.org/ csm-paper-feminism-agroecology/

Clapp, Jennifer, and Marc J. Cohen, (eds.) 2009. The global food crisis. Governance challenges and opportunities. Waterloo, Ontario: Wilfred Laurier University Press.

Committee on World Food Security (CFS). 2016. Connecting smallholders to markets. Policy recommendations. http://www.fao.org/ cfs/home/products/en/

Davis, Mike. 2000. Late Victorian Holocausts. New York: Verso Books.

ETC Group. 2018. Forcing the farm. https://www.etcgroup.org/conte nt/forcing-farm

FAO, IFAD, UNICEF, WFP and WHO. 2021. The state of food security and nutrition in the world 2021. Rome.

Friedmann, Harriet. 2015. Governing land and landscapes: Political ecology of enclosures and commons. Canadian Food Studies 2 (2): $23-31$

Friedmann, Harriet, and Philip McMichael. 1989. Agriculture and the state system: The rise and fall of national agricultures, 1870 to the present. Sociologia Ruralis. 29 (2): 93-117. https://doi.org/ 10.1111/j.1467-9523.1989.tb00360.x.
Gill, Stephen. 2019. Global governance "as it was, is and ought to be". A Critical Reflection. Global Governance 25: 371-392.

Gleckman, Harris. 2018. Multistakeholder governance and democracy. A global challenge. New York: Taylor \& Francis Ltd.

High Level Panel of Experts on Food Security and Nutrition (HLPE). 2014. Note on critical and emerging issues for food security and nutrition. http://www.fao.org/cfs/cfs-hlpe/critical-and-emergingissues/cei-2014/en/

High Level Panel of Experts on Food Security and Nutrition (HLPE). 2019. Agroecological and other innovative approaches for sustainable food systems that enhance food security and nutrition. http:// www.fao.org/agroecology/database/detail/en/c/1242141/

High Level Panel of Experts on Food Security and Nutrition (HLPE). 2020. Food security and nutrition. Building a global narrative towards 2030. http://www.fao.org/cfs/cfs-hlpe/en/

IPES-Food. 2016. From uniformity to diversity. A paradigm shift from industrial agriculture to diversified agroecological systems. http:// www.ipes-food.org/reports/

IPES-Food. 2017. Too big to feed. http://www.ipes-food.org/reports/

McKeon, Nora. 2009. The United Nations and Civil Society: Legitimating Global Governance - Whose Voice? London: Zed Books.

McKeon, Nora. 2011. Global Governance for World Food Security: A scorecare four years after the eruption of the 'food crisis.' Berlin: Heinrich Böll Stiftung.

McKeon, Nora. 2015. Food Security Governance: Empowering communities, regulating corporations. New York: Routledge.

McKeon, Nora and Gonzalo Berron. 2020. 'Introduction to Special Forum. Reclaiming democracy from below: from the contemporary state capitalist system to people's sovereignty'. Globalizations. 17(7): 1241-1264. https://www.tandfonline.com/toc/rglo20/ current

McKeon, Nora. 2016. Transforming Global Governance in the Post-2015 Era: Towards an Equitable and Sustainable World'. Globalizations

McKeon, Nora. 2018. Global food governance. Between corporate control and shaky democracy. Development and Peace Foundation. https://www.sef-bonn.org/en/publications/global-governancespotlight/22018.html

McMichael, Philip. 2018. 'Food Regime Analysis: Looking Back to Look Forward.' Keynote to the 25th Anniversary of the AustraliaNew Zealand Agri-Food Research Network, December 3, 2018.

Murphy, Craig. 1994. International organization and industrial change: Global governance from 1850. Cambridge: Polity Press.

Polanyi, Karl. 1957. The Great Transformation. Boston: Beacon Press.

Scoones, Ian and Andy Stirling (eds.). 2020. The Politics of Uncertainty. Challenge of Transformation. Sussex: Institute of Development Studies, ESRC STEPS Centre. https://www.taylorfrancis. com/books/e/9781003023845

Shaw, D. John. 2016. The Rise and fall of a United Nations body. Canadian Journal of Development Studies 30 (3-4): 663-694.

Shaw, D. John. 2007. World Food Security. A History since 1945. London: Palgrave Macmillan.

Thompson, E.P. 1963. The Making of the English Working Class. London: Victor Gollancz Ltd.

Watts, Michael. 1983. Silent Violence. Food, famine and peasantry in Northern Nigeria. Berkeley: University of California Press.

Publisher's Note Springer Nature remains neutral with regard to jurisdictional claims in published maps and institutional affiliations. 